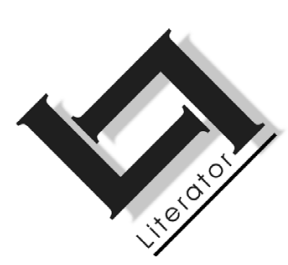

\title{
Ruimte as tema en metafoor in die poësie van enkele vroulike Afrikaanse digters: 1994-2005
}

\author{
A.M. de Beer \& H.J.G. du Plooy \\ Skool vir Tale \\ Potchefstroomkampus \\ Noordwes-Universiteit \\ E-pos: Etta.deBeer@nwu.ac.za \\ Heilna.duPlooy@nwu.ac.za
}

\begin{abstract}
Space as theme and metaphor in the poetry of selected female poets in Afrikaans: 1994-2005

This article illustrates that the representation of physical and abstract space is exceptionally prominent in the work of female poets in Afrikaans who published poetry between 1994 and 2005. The possibility that a "female consciousness" influences the use of spatial metaphors is put forward (but not proved). Following the theoretical insights of Pierre Bourdieu, the relationship between society and art is explored, and consequently the importance of the postcolonial context of Afrikaans poetry published between 1994 and 2005 forms part of the analyses of the thematic and metaphorical aspects of the selected poems. Examples of the salient aspects of representations of space, both as theme and as metaphor, in the work of female Afrikaans poets are discussed in more detail before some preliminary conclusions are put forward.
\end{abstract}

\section{Opsomming}

Ruimte as tema en metafoor in die poësie van enkele vroulike Afrikaanse digters: 1994-2005

In hierdie artikel word die belangrikheid van die representasie van fisiese en abstrakte ruimtes in die werk van vroulike digters in Afrikaans aangetoon, spesifiek in bundels wat gepubliseer is tussen 1994 en 2005. Daar word kortliks aandag gegee aan die vraag of daar sprake kan wees van 'n "vroulike bewussyn" in 
hierdie bundels. Die ruimtelike bewustheid word ook in verband gebring met die feit dat die Afrikaanse poësie in die periode 1994-2005 postkoloniaal is. Die teorieë van Pierre Bourdieu word gebruik om die verhouding tussen gemeenskap en kunswerk te verduidelik en daarna word voorbeelde van die ruimtelike tematiek asook die gebruik van ruimtelike metaforiek in die werk van geselekteerde vroulike digters bespreek.

\section{Inleiding}

In sy studie, Filosofie van het landschap, beweer die Nederlandse filosoof Tom Lemaire (1996) dat ruimte en die belewing van die ruimte in 'n kultuur nie 'n bykomstige aspek of 'n randverskynsel in die lewens van mense is nie, maar dat dit op 'n heel besondere manier die gees van daardie kultuur vasvang. Lemaire (1996:18) is ook van mening dat 'n kultuur, 'n tydperk of 'n individu sy lewensorde, verlede en verlangens in voorstellings van die ruimte projekteer. Hy (Lemaire, 1996:18) vervolg:

In dit vlak 'expliceert' een cultuur zichzelf: ontvouwt zij zichzelf en legt zichzelf tevens uit, de ruimte is 'explicatio culturae'. Zo kan men het lot van een cultuur aflezen uit de geschiedenis van de ruimte die zij bewoont en waarover zij uitkijkt.

Hieruit volg dat 'n mens bepaalde afleidings sou kon maak uit die manier waarop ruimtes in literêre tekste voorgestel word. Hierdie artikel is gebaseer op navorsing (De Beer, 2009) oor die voorstellings van ruimtes, ruimtelike tematiek sowel as ruimtelike metaforiek in die poësie van geselekteerde vroulike digters wat in Afrikaans skryf en wat in die periode 1994-2005 bundels gepubliseer het. Die vraag is of ' $n$ mens bepaalde poëtikale en/of tematiese merkers of eienskappe kan identifiseer en formuleer na aanleiding van die bestudering van die ruimtelike representasies en die gebruik van ruimtelike metafore by Afrikaanstalige vroulike digters uit die dekade rondom die eeuwisseling, spesifiek teen die agtergrond van die veranderings in die Suid-Afrikaanse sosiopolitieke werklikheid.

In die periode 1994-2005 was 'n hele aantal gevestigde Afrikaanse digters aktief, terwyl sommige ander gedebuteer het. Die literêr-historiese ontwikkeling in die Afrikaanse poësie in hierdie periode is boeiend juis omdat daar baie veranderings in die sosio-politieke omstandighede in die land plaasgevind het. Alle digters skryf die ruimtes waarbinne hulle lewe in hulle tekste in, maar reeds by die verkennende lees van die werk van verskeie Afrikaanse vroulike digters van wie tekste in hierdie periode verskyn het, is die aanwesigheid van 'n ruimtelike bewustheid opvallend aanwesig. In ge- 
digte van onder meer Elisabeth Eybers, Ina Rousseau, Wilma Stockenström, Antjie Krog, Petra Müller, Heilna du Plooy, Trienke Laurie, Melanie Grobler en Ilse van Staden is daar vele voorbeelde van die uitbeelding van ruimtelike ervaring op 'n referensiële vlak (d.w.s. verwysend na 'n leefwêreld), sowel as van die gebruik van metafore wat op ruimtelike assosiasies berus. Die digters skryf dus oor die fisiese ruimtes waarbinne hulle lewe en tematiseer ruimtelike belewenis deur kwessies soos grensoorskryding en die verkenning van nuwe ruimtes in die gedigte aan die orde te stel. Verskeie digters gebruik egter ook in verband met ander onderwerpe metafore wat met ruimtes verband hou, byvoorbeeld deur die landskap as metafoor van belewenis te gebruik of deur ideologiese en politieke versoening in terme van die uitwissing van ruimtelike afstand uit te beeld, soos verderaan aangetoon sal word.

Uit die titels van die bundels van hierdie genoemde Afrikaanse vroulike digters blyk ook al hoe sterk 'n ruimtelike bewussyn en die verskillende fasette van ruimte in die bundels figureer. Voorbeelde van sulke titels is Aan die Kaap geskryf (Wilma Stockenström, 1994), Interne verhuising (Joan Hambidge, 1995), In die landskap ingelyf (Heilna du Plooy, 2003), Die stil middelpunt (Ina Rousseau, 2003), Uit en tuis (Elisabeth Eybers, 1995) en Landelik (Martjie Bosman, 2002). Ander vrouebundels uit hierdie tydperk waarin die tematiek sterk met plek en ruimte gemoeid is, is Skietspoel (Trienke Laurie, 1997), Die donker is nooit leeg nie (Heilna du Plooy, 1997), Wintersurplus (Elisabeth Eybers, 1999), Die skaduwee van die son (Lina Spies, 1998), Kleur kom nooit alleen nie (Antjie Krog, 2000), Ewebeeld, Ruggespraak en Lykdigte (Joan Hambidge, 1997; 2002; 2000), Lyfsange (Marlise Joubert, 2001), Die aandag van jou oë: gedigte vir die liefde (Petra Müller, 2002) en Watervlerk (Ilse van Staden, 2003). In hierdie bundels is, soos later met voorbeelde aangetoon sal word, die interaksie van mense - spesifiek van vroue - met die plekke waar hulle woon en leef en die ruimtes waarin hulle beweeg en wat deur hulle ervaar word, opvallend. Daar word ook dikwels gebruik gemaak van metafore wat op die een of ander manier met ruimtelike konsepte te make het.

\section{Belangrike kontekstuele faktore}

Wanneer daar na die representasies van ruimte in die poësie van die digters wat hierbo genoem is, gekyk word, blyk dat daar in die periode wat ondersoek word, twee belangrike kontekstuele faktore verreken moet word: die sterk "vroulike selfbewussyn", meer spesifiek die feministiese diskoers, asook die postkoloniale omstandig- 
hede in die land. Die fisiese ruimtes en die abstrakte ideologiese en politieke ruimtes word deur die politieke ontwikkelings in die land beïnvloed en bepaal, en vroulike digters is as vroue daaraan onderworpe. Die werklikheid, konkreet én abstrak, word dus telkens verwoord soos wat dit deur die psige van 'n vroulike digter gefilter is. Die vraag kan dus ontstaan of vroulike ervaring van die ruimtelike aspekte van die werklikheid, al is dit nie altyd eksplisiet feministies van aard nie, 'n bepaalde aard of vorm aanneem. In hierdie artikel word die feminisme en die postkolonialisme nie uitvoerig teoreties verken nie, hoewel die uitgangspunte van en aannames binne hierdie twee benaderings tot die literatuur onvermydelik in die voorbeelde en die argument ' $n$ rol speel. Die bespreking word beperk tot enkele tersaaklike aspekte van die feminisme en die postkolonialisme soos wat dit 'n rol speel in die verse wat ter sprake gaan kom.

\subsection{Die "vroulike" diskoers en "vroulike" ruimtes}

Hoewel die meeste vrouedigters wat in Afrikaans skryf hulleself as selfstandig-denkende en geëmansipeerde mense beskou, blyk uit die openbare diskoers in tydskrifte en koerante en ook uit sommige literêre tekste dat die persepsie steeds bestaan dat vroue in al die Suid-Afrikaanse gemeenskappe dikwels nog 'n sekondêre rol vertolk. Na 1994 beleef Suid-Afrika 'n opbloei in demokrasie sodat daar in die openbare lewe sterk standpunt ingeneem word oor die deurlopende ontmarginalisering van vroue. Hulle moet in staat kan wees om grense te oorskry en nuwe ruimtes te betree. Hierdie tendens sluit aan by die internasionale diskoers oor die posisie van vroue, veral van skrywende vroue.

Een vraagstuk wat telkens weer na vore kom, gaan oor die aard, tematies en vormlik, van vroulike representasies. Moi (Belsey \& Moore, 1997:105) voer aan dat alle persepsies, insluitend feministiese persepsies, gekontamineer is deur die patriargale ideologie. In die negentiende eeu (en tans steeds) presenteer die dominante patriargale ideologie kunskreatiwiteit as ' $n$ fundamentele manlike kwaliteit: "The writer 'fathers' his text." (Moi, 1985:57.) Vroue word van hulle reg ontneem om hulle eie persepsies van vroulikheid te skep. In plaas daarvan word hulle gedwing om by die patriargale denkpatrone in te skakel of daarop te reageer, omdat hierdie patrone die norme van die gemeenskapsdenke, van die filosofie, die literatuur en ander voorstellings vasstel en bepaal. 'n Ondersoek na die werk van Afrikaanse vroulike digters rondom die afgelope eeuwending toon egter dat daar 'n baie bewuste ontginning van 'n persoonlike selfbewussyn is, maar ook dat selfkennis en selfrepresentasie on- 
losmaaklik verbonde is aan leefruimtes en ruimtelike belewenis in sosiale en ideologiese $\sin$. $^{1}$

Die onderskeid tussen die publieke en private ruimte is ' $n$ ander belangrike digotomie in die diskoers rondom vroulikheid en vroulike belewenis en representasie. Viljoen (2002) ondersoek die kwessie van vroulike ruimtes in die werk van vier digters wat almal in 1970 gedebuteer het en ook almal met die Hertzogprys bekroon is en toon so die relevansie van die ruimteproblematiek in vroueskryfwerk aan.

Private ruimtes, soos die huis, is tradisioneel met vroue geassosieer en publieke ruimtes, soos die parlement, die mark en die geregshof, met mans en húlle aktiwiteite. Volgens geograwe is die private as tipe tradisioneel verbind met die huis, die liggaam, die natuurlike, die familie, die persoonlike lewe, intimiteit, passie, versorging, 'n toevlug, onbetaalde arbeid, reproduksie en immanensie. Hierteenoor is die publieke domein as tipe tradisioneel verbind met die nie-liggaamlike, die abstrakte, die kulturele, rasionaliteit, burgerskap, die reg, die markplek, betaalde arbeid, produksie, die staat, handeling, militarisme, heroïsme en transendensie (Viljoen, 2002:3).

Bogenoemde onderskeid kom steeds na vore in die politieke filosofie, die regstelsel, die algemene diskoers en ook in die terugkerende ruimtelike strukturerende praktyk en as sodanig bly dit 'n sentrale vraagstuk in die feministiese diskoers oor magsverhoudings. Sommige feministe glo dat die digotomie tussen die private en die publieke dié sentrale kwessie in die feministiese stryd is, terwyl ander weer daarop wys dat hierdie onderskeid eintlik kenmerkend is van die middelklas en dat dit nie noodwendig op presies dieselfde wyse in ander klasse en gemeenskappe resoneer nie (Blunt \& Rose, 1994:3-4).

Alhoewel die digotomie tussen die publieke en private ruimtes 'n binêre opposisie suggereer, is dit vals om te argumenteer dat albei hierdie kategorieë klinkklaar gedefinieer is, omdat nie alle ruimtes duidelik privaat of publiek is nie. Die letterkunde is een van die velde waar geslagtelike belewenis van ruimte 'n rol speel en gerepresen-

1 Die problematiek word uitvoeriger uitgewerk en met veel meer voorbeelde in De Beer (2009) toegelig. Hier word met die kernargumente en enkele voorbeelde volstaan om die aandag op die verskynsel te vestig wat ook nog veel wyer ondersoek moet word. Om uitvoeriger bewysvoering aan te bied, sal die navorsing ook uitgebrei moet word deur die werk van vroulike digters met dié van manlike digters te vergelyk. 
teer word. Dit is daarom ook 'n terrein waar mededinging en heronderhandeling van geslagtelik gemerkte ruimte plaasvind. Dit gebeur op verskillende maniere, soos die subtiele verskuiwing met betrekking tot die konvensionele waardes geheg aan bepaalde ruimtes, die herwaardering van ruimtes wat met tipiese vroulikheid geassosieer is, pogings om daardie ruimtes radikaal anders te vul en ook om die private en die publieke met mekaar te laat versmelt.

Dat die huishoudelike ruimte byvoorbeeld ' $n$ rol in die Afrikaanse letterkunde speel, blyk reeds uit die bestaan van die term "huishoudelike poësie". Elisabeth Eybers het reeds vroeg in haar loopbaan op die geringskatting van hierdie soort poësie gesinspeel toe sy in 'n brief aan Van Wyk Louw (ironiserend) geskryf het dat sy as huisvrou dalk in die toekoms "n poësie van potte en panne" sal skryf. Ina Rousseau het ook soos Elisabeth Eybers in haar poësie op die tradisionele definisies van vroulike ruimtes gereageer. Ook Sheila Cussons se kombuisgedigte toon aan hoedat sy die geslagsbepaaldheid van die betrokke ruimte verwerk. Die lyn kan ook vanaf Cussons deurgetrek word na opvolgers soos Lina Spies en Antjie Krog (vgl. Viljoen, 2002:8-11).

Die oorskryding van die grens tussen binneruimtes soos die huis en tuin en die groter wêreld buite is baie prominent in die bundels wat tussen 1994 en 2005 verskyn, veral as die teenstelling ook wyer beskou word as net "huis" teenoor "buitewêreld". In die versamelbundel Die stil middelpunt: 'n keur, met nuwe gedigte van Ina Rousseau word die "Nuwe gedigte" in die laaste afdeling bymekaargebring. Tussen die 21 gedigte in die afdeling is daar dertien wat op die een of ander manier te make het met die onderskeid tussen "buite" en "binne" en met die spanning tussen die verskillende ruimtes.

In "Die Purkinjé-verskynsel” (Rousseau, 2003:150) onthou die spreker in die gedig hoe sy die beperking van 'n treinruimte jare gelede kon oorskry deur 'n bepaalde metaforiese visie op 'n laning vlierbome. Dit was vir haar asof die laning blomme teen die lug verf sodat die vaalte van die landskap deur haar manier van kyk getransformeer is. Die gesprek oor donkerte waarna aan die begin van die gedig verwys word, word beantwoord deur 'n bevrydende herinnering op te roep: die manier van kyk, vanuit 'n binneruimte na 'n groter buiteruimte, maar ook 'n verbeeldingryke beskouing van daardie buiteruimte, kan 'n vaal landskap "triomfantlik" verander. Daar is by die digter geen selfbewustheid oor die feit dat sy haar herinnering as belangrik weergee nie, hoewel "beeldsluierwit blomme" as 'n "vroulike metafoor" beskryf kan word. Wat verder belangrik is, is dat 
die waarnemer en spreker as 'n reisende mens voorgestel word wat haar ervaringswêreld konstrueer en rekonstrueer deur "na buite" te kyk.

Toe hulle praat oor een of ander naderende donker

onthou ek dat ek jare gelede gesien het, deur 'n treinruit een vroegaand in Vlaandere,

hoe 'n lang laning vlierbome kilometer ná kilometer

honderde haarskerp omraamde bruidsluierwit blomme

triomfantelik verf op die halflug se vaalte.

(Die stil middelpunt; Rousseau, 2003:150.)

Sterker gemoeid met die problematiek van Suid-Afrika is die versreeks "Die seuns en die dogters van die mense 1-4" (Rousseau, 2003:161-164) waarin die herhaalde weggaan en terugkom van kinders kommentaar lewer op die opvoeding van Suid-Afrikaanse kinders, maar ook op die situasie in die land. In die gedig "Koerant" (Rousseau, 2003:155) word die veilige ruimte van die binnehoffie gekontrasteer met die skokkende nuus oor die buitewêreld waarvan in die koerant gelees kan word. In "Kersfees 1996" word 'n menseslagting gekontrasteer met die "voldane" manier waarop 'n mens in hulle huis voor die venster die kersete opdis. Die sensitiwiteit in die gedigte kan wel as "vroulik" beskou word en ook die waarnemingspunt wat "binne" die beskermde ruimte lê, maar die bemoeienis met die groter problematiek, die betrokkenheid by groter vraagstukke oorskry die grens van die tradisionele "binneruimte" van vroue.

In die gedig "Die vorm" (Rousseau, 2003:154) word die dreiging van 'n katastrofale uitbarsting oor grense heen gesuggereer sodat die angstigheid oor die situasie in die land en die kontinent indirek aan die orde gestel word. 


\section{Die vorm}

Hier is die wêreldkaart: spits

jou aandag toe op Afrika, waar hy

veeltintig voor jou lê. Neem waar:

$\mathrm{Hy}$ is topswaar, kromlynig en enorm -

rofweg die vorm

van 'n gestolde kernbomontploffing.

(Die stil middelpunt; Rousseau, 2003:154.)

In al hierdie gedigte kan gesien word hoe intens die bewustheid van die dinamiek rondom grense is. Daar is geen sprake van in een ruimte vasgevang bly nie; trouens, die spanning tussen ruimtelik geskeie wêrelde wat albei deur die spreker bewoon en betree word, vorm telkens die kern of die kruks van die gedig.

\subsection{Die postkoloniale konteks}

Een van die belangrikste faktore in die ontwikkeling van die Afrikaanse letterkunde is die koloniale en postkoloniale geskiedenis. Trouens, daar kan selfs beweer word dat dit die enkele belangrikste historiese gegewe in die totale geskiedenis van Suider-Afrika is. Volgens Ashcroft (2001:1) is die kolonialisme nog steeds 'n bepalende faktor en word die kulturele en politieke aard van die kontemporêre wêreldproblematiek grootliks bepaal deur die erflating van die volgehoue uitbreiding van Westerse moondhede vanaf die tyd van die Renaissance tot in die negentiende eeu.

In die algemeen word aanvaar dat postkoloniale literatuur die resultaat is van die interaksie tussen 'n imperiale kultuur en die kompleksiteit van inheemse kultuurpraktyke in die gekolonialiseerde gebied. Volgens Hutcheon (1995:130-135) is daar egter 'n noue verband tussen postkolonialisme en feminisme vanweë die sterk politieke agenda wat albei diskoerse kenmerk, asook vanweë hulle betrokkenheid by sosiale en politieke hervorming. In die postkoloniale diskoers staan die koloniale subjek sentraal, terwyl die fokus in die postmoderne diskoers op die humanistiese val, en dus ook op die spesifiek vroulike subjek (vgl. Moore-Tilbert et al., 1997:6).

In Antjie Krog se Kleur kom nooit alleen nie en Wilma Stockenström se Spesmase word implisiet en eksplisiet 'n verband gelê tussen manlike dominansie en koloniale vergrype en politieke en maatskaplike geweld. Daar is talle voorbeelde, maar hier word slegs verwys na die gedig "ai tog!" van Antjie Krog (2000:47) waarin die vrou geteken word as die een wat inderdaad "woordeloos" die grense tussen mense en kulture oorsteek: 
mens hoort by haar wat daagliks woordeloos nuwe wolle by die mat vleg

(Kleur kom nooit alleen nie; Krog, 2000:47.)

Volgens Odendaal (2006:126-127) bevat hierdie gedig 'n besondere sterk uitspraak teen Afrikanermans se

male vanity wat die laaste woord spreek

oor die voorwaardes van by hulle hoort

...

(en 'n taal besig gestroop van die grammatika

van menslikheid en berou)

(Kleur kom nooit alleen nie; Krog, 2000:47.)

Hoewel "wolle vleg" eksplisiet 'n tradisioneel vroulike handeling is, is die optrede van die vrou wat haar oor kultuurgrense heen by hierdie aktiwiteit aansluit en "voeg", 'n grensoorskrydende handeling. Handeling en dade het tradisioneel tot die manlike domein behoort en die vrou in die gedig verbreek die tradisionele beperking tot bepaalde ruimtes of domeine. Sy maak die grens van die verlede "inderdaad" ongeldig. Wat ook belangrik is, is dat sy nie heeltemal na 'n ander ruimte oorgaan nie, maar dat sy die handelende ingesteldheid versoen met die vroulike domein deur aan 'n vroulike handeling mee te doen. Die versmelting en versoening van voorheen geskeide ruimtes word hier subtiel gesuggereer.

Hierdie gedig staan aan die slot van afdeling 2 van die bundel, waarin dit gaan oor allerlei vorms van geweldpleging in Suider-Afrika (die Anglo-Boereoorlog, die struggle-tydperk in die laaste deel van die twintigste eeu, die plaasbesettings in Zimbabwe). Gekoppel aan 'n uitspraak soos die volgende uit die slotafdeling van die bundel, waar ook ander dele van Afrika betrek word, is dit duidelik dat die mans van Afrika besonder negatief uit die prentjie te voorskyn kom:

ek sal jou kom haal uit beendere en koeëls en geweld en vigs uit stomheid uit domheid uit die korrupte gesigte van mans (Krog, 2000:81).

Die noue verband tussen die ruimte van koloniale vergrype en politieke en maatskaplike geweld, en die vroulike ervaring daarvan, blyk uit vele soortgelyke gedigte waarin die stem van die vrou in SuidAfrika sterk na vore kom. Die vrou is die een wat deur al die ruimtes heen beweeg en sodoende 'n brug slaan tussen wêrelde. Sy gaan werk saam met die ander kultuur se vroue en gaan haal die man uit die geweldsones. Sy is dus ook daadkragtig en tree op buite die tradisionele vroulike rol en oorskry so die grens van die beskutte 
ruimte. Sy doen alles egter op 'n vroulike manier deur versoening, vrede, geweld en redding te bevorder.

Uit bogenoemde voorbeelde wil dit voorkom asof daar wel ' $n$ bepaalde vroulike siening van die werklikheid is wat duidelik uit die representasies van belewenis en die werklikheid in die gedigte na vore kom, in sowel die tematiek as die metaforiek in die gedigte.

\section{Die literatuur as 'n "produk" in en van die gemeenskap}

Dit bly altyd ' $n$ vraag of daar enige sinvolle afleidings gemaak kan word op grond van die temas waaroor digters skryf en of daar inderdaad 'n oorsaaklike verband tussen kontekstuele faktore en die poësie is, aangesien die poësie, veral liriese poësie, tradisioneel juis tyd en ruimte wil transendeer. Hieruit voortvloeiend is ook die vraag of die poësie 'n uitwerking op die gemeenskap van lesers het deur mense te beïnvloed, hulle sienings te verander en deur insig oor te dra. Hierdie vrae geld ook vir die vrouedigters wat rondom die eeuwending in Afrikaans skryf. Watter geldige afleidings kan gemaak word oor wat hulle skryf en hoe hulle skryf? Sou hierdie afleidings inligting verskaf oor of insig bied in die werk van die spesifieke digters alleen, of sou daar ook iets aangaande die gemeenskap waarbinne hulle leef en skryf na vore kom?

Kan 'n mens aanvaar dat wanneer 'n bundel deur 'n uitgewer gekeur is, dit impliseer dat wat in die bundel staan en die manier waarop die tematiek in die bundel hanteer word, relevant en belangrik is vir die gemeenskap aan wie die bundel aangebied word? Is die uitgewer se siening en oordeel geldig en hoe korreleer dit met die markwaarde, dit wil sê gaan mense regtig die bundel koop? Is die verkope van die bundel 'n geldige maatstaf vir relevansie en gehalte? Die veronderstelling is immers dat die uitgewer besluit of die bundel bemarkbaar is en dat hierdie besluit met gehalte, aktualiteit en die versoenbaarheid met 'n bepaalde kulturele, ideologiese, politieke en sosiale klimaat verband hou.

Hierdie vraagstelling sluit aan by die sienings van die Franse kultuursosioloog, Pierre Bourdieu, aangesien die interaksie tussen die magstrukture van ekonomiese en kulturele stelsels te make het met die "reëls van die spel" waarbinne alle kulturele produkte funksioneer. In elke gemeenskap beklee bepaalde sake en instellings magsposisies en op grond van die verhoudings tussen hierdie posisies speel daar op verskillende vlakke en terreine 'n magstryd af. 
Bourdieu is een van die teoretici wat die wisselwerking tussen teks en konteks sentraal stel en uitvoerig skryf oor hoe die ideologiese, ekonomiese en kulturele magsverhoudings in 'n gemeenskap kulturele produkte en hulle bestaan en oorlewing beïvloed (Bourdieu, 1992; 1994). In aansluiting by Foucault en Habermas (Bezuidenhout, 2005:37), hou hy hom spesifiek besig met die rol en funksionering van estetiese objekte binne 'n bepaalde gemeenskap en die faktore wat die interaksie tussen gemeenskap en teks bepaal (Bourdieu, 1994:252). Hy is van mening dat die leser hom-/haarself nie moet blindstaar teen die teks nie, maar ook die maker (digter en sender van 'n boodskap) in ag moet neem, sowel as die konteks en die blik van die ondersoeker as sodanig (vgl. ook Bezuidenhout, 2005:37).

Volgens Bourdieu (1992:12-13) kan die domein waarbinne die literatuur funksioneer, deur 'n driehoeksverhouding tussen drie grondbegrippe beskryf word, naamlik veld, habitus/habitat en kapitaal. Veld dui op die bestaan van die "wêreld", die sosiale universum, wat volgens 'n onherleibare eie logika funksioneer, al tree daar tussen die verskillende velde allerlei strukturele en funksionele homologieë op. ' $n$ Veld is 'n netwerk of konfigurasie van objektiewe verhoudings tussen objektiewe gedefinieerde posisies wat deur akteurs of "actoren" beklee word en wat dus as habitus die veld bevolk. Daar is 'n stel verhoudings tussen posisies wat die uitwendige struktuur van die veld bepaal en daar ontstaan stryd tussen die posisies in die veld. Elke veld ken een spesifieke vorm van kapitaal (of mag) wat ongelyk verdeel is en waarvan die besit toegang verleen tot die spesifieke wins wat op die veld behaal kan word. Elke veld veronderstel die beheersing van die "reëls van die spel", 'n stilswyende erkenning van die waarde van die spel en die inset daarvan. Alhoewel alle velde deelnemers aan die spel het, wat belange investeer en deel, is alle velde strydperke waar 'n onafgebroke stryd woed om die verdeling van mag (of kapitaal). Daar is ook deurlopend stryd om die behoud van of die verandering van die struktuur en die grense van die veld self, dit wil sê die definisie en funksionering van die legitieme veldpraktyk insluitend prosedures en deelnemers (dié wat mag en nie mag deelneem aan die spel nie).

Afrikaanse digters soos Krog en Stockenström se werk tree duidelik en sterk in gesprek met die ideologiese kwessies in die werklikheid. Die onderwerpe en temas waaroor hierdie digters skryf, hou dus verband met die dinge wat in die gemeenskap as kapitaal (volgens Bourdieu se terminologie) beskou word, naamlik die hoop, vrees, politieke belange en laste van mense. Die inhoud as sodanig en die 
standpunte wat verwoord word, is dus aktueel vir die kontemporêre gemeenskap en daarom is die werk relevant en goed bemarkbaar. Dieselfde geld vir die habitus, dit wil sê die mense wat die veld bevolk en die magsverhoudings tot stand bring en in stand hou.

Indien hierdie struktuur toegepas word op die skryf, die publikasie, die bemarking en lees van die poësie op 'n bepaalde tyd in die geskiedenis, blyk dat selfs die poësie wat altyd as "belangeloos" en "vry" beskou is, binne 'n stelsel van magsverhoudings funksioneer. 'n Uitgewer beoordeel (met behulp van buite-keurders) 'n manuskrip en besluit of dit relevant, miskien selfs hoogs aktueel, ideologies riskant of literêr van hoë gehalte is. $\mathrm{Na}$ aanleiding van die posisie van die uitgewer binne die ekonomiese en ideologiese magsverhoudings word besluit of die bundel gepubliseer word of nie. Een uitgewery kan 'n gewaagde en vernuwende manuskrip aanvaar omdat dit potensieel 'n goeie wins sal oplewer, terwyl 'n ander dieselfde manuskrip ter wille van literêre meriete sal wil publiseer, afhangende van die waardesisteem waarvolgens die uitgewer funksioneer. Die uitgewer se optrede word deels deur die ekonomiese en ideologiese omgewing bepaal, maar ook deur die gemeenskapsopvattings. Soms kan die uitgewer voel dat hy die gemeenskap wil uitdaag, maar soms wil en moet die uitgewer bloot geld maak. Daar is talle beperkende of bepalende reëls wat die literêre veld beïnvloed en 'n digter se werk staan nooit los daarvan nie.

Hoewel daar sekerlik digters is wat probeer om buite die stelsels te bly, is dit rondom die eeuwisseling na die 21e eeu juis deel van die kontekstuele gegewens dat aktualiteit belangrik is. Baie digters se werk sluit aan by die kontemporêre kwessies en dilemmas, omdat dit 'n produk is wat binne die stelsel hoort, daaraan deelneem en dit uitbou. Daar is in die literêre veld oor eeue heen 'n eb en vloed van gesindhede oor die belang van betrokkenheid in die poësie, maar in die teenswoordige tydsomstandighede word dit wel hoog aangeskryf. Werk van individualistiese aard wat voortreflik is, sal waarskynlik egter steeds deur die "regte" uitgewer uitgegee en bemark word.

Die interaksie tussen gemeenskap en/of individu en die sosiopolitieke omwêreld is prominent in die werk van verskeie Afrikaanse vrouedigters in die dekade rondom 2000. Stockenström en Krog se werk kom hier onder meer ter sprake, omdat hulle 'n sterk sosiopolitieke bewussyn in hulle werk openbaar. Ander vroulike digters wat by hulle aansluit is Rousseau, Spies, Laurie, Du Plooy en Joubert. Die wêreld waarin die poësie gelees word en die wêreld waarna in die poësie verwys word, stem dus ooreen in terme van 
die magsverhoudings en dominante kwessies wat daarin weerspieël word.

Wat egter vir die argument in hierdie artikel belangrik is, is dat hierdie betrokke ingesteldheid in baie gevalle met die ruimte te make het en in terme van ruimtelike metafore uitgedruk word soos later met voorbeelde geïllustreer sal word (vgl. paragraaf 4).

Bourdieu (1994:284, 287) se siening is dat tekste (die kapitaal van die veld) wat geskryf en uitgegee word nie werklik vry is nie. Hy benadruk dat op bepaalde tye in die geskiedenis spesifieke maatskaplike faktore sentraal staan en die kreatiwiteit en die status van 'n digter in werklikheid (kan) strem en/of stuur. Dit kom daarop neer dat kunsproduksie en -verspreiding dus, in bepaalde tydperke, deur historiese omstandighede gedetermineer word. Volgens Bourdieu is die outoriteit en mag van die skrywende genie 'n illusie wat, hoe indirek ook al, onderworpe is aan die spel van veranderlikes - 'n verskynsel wat hy "die reëls van die kuns" noem.

'n Mens kan hierdie stelling se algemene geldendheid bevraagteken omdat daar tog deurlopend vernuwing van sowel tematiek as styl in die literatuur voorkom en veranderings in estetiese opvattings en praktyk is dikwels juis teenstrydig met die verwagte ideologiese en kulturele verwagtings. ${ }^{2}$ Wat wel uit Bourdieu se opvattings afgelei kan word, is dat tekste en die gesitueerdheid van skrywers, onder die vroulike Afrikaanse digters rondom die eeuwending, deur gebeure in die sosiale bestel sowel as die literêre veld gerig word. Hiervolgens kan aangeneem word dat kwessies van vryheid en bevryding van vroue in Suid-Afrika ook in die Afrikaanse digters se werk gereflekteer sal word (vgl. Bezuidenhout, 2005:37). Hoewel dit sekerlik nie die deurslaggewende faktor is vir Krog se statuur as digter nie - omdat die estetiese gehalte en trefkrag van haar unieke hantering van taal, ritme, metaforiek en versvorm onbetwisbaar is speel die betrokke tematiek in haar werk tog 'n belangrike rol in die gesogtheid van haar bundels. Dit is ook deels hierdie deelname aan 'n dwingend belangrike diskoers wat Krog se werk in Suid-Afrika en in die buiteland hoogs bemarkbaar maak. Krog se reputasie as 'n prominente eietydse Afrikaanse digter berus ook daarop dat sy die

2 Die Sestigerbeweging is hiervan ' $n$ uitstekende voorbeeld aangesien die vernuwing van Sestig juis 'n breuk met heersende opvattings bewerkstellig het. Dit kan egter ook 'n latente behoefte aan verandering weerspieel as daar so 'n vernuwing voorkom. Dit is egter ' $n$ ander debat om die redes en variante van vernuwing te beredeneer. 
ontwikkeling van dilemma tot verandering van die mense wat tot dieselfde taal- en kultuurgemeenskap as sy behoort, in haar verse verwoord. In elke bundel word haar eie wêreld en die wêrelde waarmee sy in gesprek tree, verruim. Haar bemoeienis met die kontemporêre politieke posisionering en haar kommentaar daarop is duidelik in versreëls soos die volgende in die gedig "ai tog!" uit die bundel Kleur kom nooit alleen nie (Krog, 2000:47). Sy relativeer die sterk groepsidentiteit wat tradisioneel deel van die Afrikaanse kultuur was en stel die moontlikheid van 'n meer universele "mens" en menslikheid voorop.

\section{mens sê maar gereeld}

mens is niemand se Afrikaner nie

mens praat niemand se taal nie

mens is nie ' $n$ moer iemand se meriete nie

mens is drolwit en pisswart

mens skyt graag op die manne

wat werk by die nuwe barcounter van identities

Benewens Krog se werk, toon die omvang en gehalte van Stockenström se publikasies dat vroue nie langer 'n marginale posisie in die Afrikaanse poësie beklee nie. Stockenström konstrueer onder andere in die gedig "Jy sien haar nêrens meer nie" in die bundel Spesmase (1999:43) 'n ek-spreker met 'n sterk bewustheid van die feit dat die rol van die vrou in die samelewing ingrypend verander het, as die gedig verwys na die "vrou / wat 'n eie vaandel dra en haarself / dodelik seker promoveer tot stryder?"

Bourdieu se siening (1996:252-253) dat interne worsteling deels deur eksterne goedkeuring gearbitreer word sluit nóú aan by bogenoemde twee digters se geïmpliseerde poëtikas. Al sou die konflik wat in die literêre teks gerepresenteer word, primêr met individuele ervaring te make hê en dus onafhanklik van eksterne en kontekstuele faktore staan, is daar steeds 'n verband tussen die trefkrag van die uitgebeelde konflik en die eksterne wêreld of werklikheid. Lesers reageer op die uitbeelding omdat die konflik, stryd of worsteling vir hulle bekend is, omdat hulle daarmee kan identifiseer of daarmee simpatie kan hê. Volgens Bourdieu (1994:142-143) speel die sosiale struktuur en die hiërargie van vraagstukke 'n bepalende rol in die produksie en die resepsie van tekste. In die praktyk is die skryfhandeling 'n produk van twee geskiedenisse: die geskiedenis van die produksie/skepping van 'n posisie wat deur 'n bepaalde skrywer of teks geokkupeer word en die geskiedenis van die produksie/skepping van die ingesteldhede van die ontvangers. 
In werklikheid is die literêre veld, net soos die politieke veld of enige veld, 'n terrein van stryd en kompetisie. Die stryd word onder meer bepaal deur spesifieke insette en spesifieke verhoudings tussen onder meer die gemeenskap, die omstandighede van die gemeenskap, die skrywers se posisie en die tematiek van die tekste. Op grond van hierdie verhoudings en die posisies van die rolspelers of agente, word die mag en invloed van die teks en die aansien van teks en skrywer bepaal. Vanselfsprekend is die bepalende magte nie net ideologies en ekonomies van aard nie, maar speel estetiese oorwegings en opvattings ook 'n rol. Bourdieu se sienings staan natuurlik self binne ' $n$ bepaalde ideologiese paradigma wat markkragte en politieke kragte as die magsbepalers beskou. Hy kwalifiseer egter self ook die spesifieke posisie van die poësie as 'n voortdurend veranderende en selfvernuwende veld.

Volgens Bourdieu (1994:143) is die poësie die lokus van 'n permanente opstand: die nuwe inskrywers bevraagteken telkens opnuut dit wat in die vorige revolusie teen die voorafgaande ortodoksie gerig was. Hierdie voortdurende opstand teen die maghebbers of heersende groep kan op die vlak van die literatuur beskou word as 'n proses van "suiwering". Poësie word meer en meer gereduseer tot die essensie daarvan; met ander woorde dit word deur herhaaldelike revolusie gestroop van dit wat poësie definieer, naamlik die rym, metrum, metafoor, liriek, ensovoorts, maar ook telkens opnuut gedefinieer.

'n Mens sou dus kon sê dat daar 'n oorsaaklike verband bestaan tussen die posisie of gesitueerdheid van digters, die manier waarop hulle hulle posisies en kommentaar daarop verwoord (dit wil sê die stemme in die poësie) en die resepsie of ontvangs van die poësie. Hierdie verskynsel kan ook in die Afrikaanse en Suid-Afrikaanse poësie opgemerk word.

\section{Gedigte in die Afrikaanse literêre veld 1994-2005}

In 'n studie oor die voorstelling van verskillende aspekte van Afrika in die Afrikaanse digkuns, toon Van der Merwe (1999) aan hoe intens die Afrikaanse poësie tot selfs in die negentigerjare van die twintigste eeu gemoeid is met die Afrikaruimte, fisies sowel as abstrak, letterlik sowel as metafories.

Van der Merwe (1999:395) identifiseer agt Afrikakodes wat prominent figureer in die Afrikaanse digkuns tot aan die einde van die twintigste eeu, naamlik 'n geografiese kode, klimatologiese kode, natuurkode, antropologiese kode, taalkode, literatuurkode, geskie- 
deniskode en 'n konflik-en-versoeningskode. Wat vir hierdie argument belangrik is, is dat ruimtelike aspekte soos die geografie, klimaat en natuur ook sterk figureer in die werk van vroulike digters rondom die wending na die $21 \mathrm{e}$ eeu.

Odendaal (2006:105) wys daarop dat in bundels soos Spesmase (Stockenström, 1999), Kleur kom nooit alleen nie (Krog, 2000), Landelik (Bosman, 2002) en In die landskap ingelyf (Du Plooy, 2003) die identiteitsvraagstuk (waarskynlik gestimuleer deur die transformasie in die land) prominent is, maar dit is opvallend dat hierdie probleem dikwels in terme van die fisiese en ideologiese ruimtes uitgebeeld word.

Die identiteitsproblematiek is veral prominent in Krog se bundel Kleur kom nooit alleen nie (2000). Krog rekonstrueer haar Afrikaansheid dialogies binne die Afrikakonteks deur ander stemme in haar poësie te laat praat. Dit word gedoen deur die teenoor- en langsmekaarplasing van belewenisse van verskillende kultuurgroepe en deur mense uit verskillende groepe aan die woord te stel (die parkboer, die lydende vroue aan die begin en aan die einde van die eeu, die digters van Wes-Afrika). Krog is egter deurlopend bewus van die intensiteit van die Afrikaproblematiek en is ook uitgesproke en krities oor nuwe polities-maatskaplike stelsels wat ontwikkel in die bevryde Afrika. In "ná grond-invasions in Zimbabwe" van Krog (2000:45) word sulke sake gereleveer in die volgende versreëls:

sal 'n swart man op 'n dag in my gesig gil

Voetsek! Fôkôf! en my huis oorvat

en my President bly stil en sy Kabinet

en die oorblywende wit comrades?

(Kleur kom nooit alleen nie; Krog, 2000:45.)

Hoewel die argument in hierdie bundel as geheel gaan oor die moontlikheid dat wedersydse respek en medemenslike liefde persoonlike heling bring en dat identiteit eers daarna kan ontwikkel, verwoord hierdie gedig 'n werklike vrees by die digteres, ' $n$ vrees wat ook deur lesers gedeel sal word. Die feit is dat haar soeke na identiteit in hierdie bundel onlosmaaklik aan die Afrikaruimte verbonde bly. In die bundel word trouens 'n lang reis afgelê om by 'n bepaalde, gekwalifiseerde identiteit uit te kom, 'n identiteit waarin sowel Afrikaans as Afrika, taal en plek en die baie verhoudings daaromheen 'n rol speel. 


\subsection{Reis as motief en identiteit}

Daar bestaan 'n sterk verband tussen reis ('n ruimtelike verplasing) en identiteit. Reis is 'n opvallende tema wat op 'n verskeidenheid maniere ontgin word in die werk van Afrikaanse vroulike digters tussen 1994 en 2005. Die vele reisgedigte toon in hoe 'n mate die ruimte van die huis en tuin en die kleiner ruimtes van die tradisionele vroulike bestaan deurbreek is. Die soeke na identiteit deur middel van reis figureer byvoorbeeld sterk in Hambidge se poësie en dit gaan dan uiteindelik in Lykdigte (2000) oor die finale oorgang na die doderyk. In Hambidge se oeuvre gaan dit egter hoofsaaklik om 'n persoonlike identiteitsoeke deur middel van reise.

In In die landskap ingelyf (Du Plooy), Die skaduwee van die son (Spies), [en die here het foto's geneem oor vanderbijlpark] (Nel) en Kleur kom nooit alleen nie (Krog) word indrukke van die besoekte wêrelddele poëties verwerk, maar die ervaring van vreemde ruimtes geskied teen 'n bepaalde agtergrond van ruimtelike verbondenheid.

In Du Plooy se bundel, In die landskap ingelyf (2003), word die verbondenheid aan 'n spesifieke plek en 'n spanning tussen die reis en die plek van herkoms, die tuiste, verwoord ter inleiding van 'n reeks gedigte oor reise na verre plekke. Die sentrale gedagte is dat hoewel die spreker die behoefte het aan reis, aan uitbeweeg, aan die verkenning van nuwe plekke en die oorskryding van bekende horisonne, die verbondenheid aan die plek van herkoms nie daardeur prysgegee of gekompromitteer word nie.

I

my hart se een voet kan nie loop nie.

my hart se ander voet loop rond.

my hart stuur arms, kop en een

voet ver en wyd reislustig uit.

die ander voet bly tuis.

(In die landskap ingelyf; Du Plooy, 2003:48.)

Die behoefte aan 'n wyer ervaring word ook uitgespreek in die volgende gedig van Nel:

dus aarde hier is ek

gereed om jou pad nog 'n keer te pak

en weer te stap

om meer te weet en weer te sien

en nog en nuwe songs te leer

en ek wag op jou

om uit te vind 
die tyd vir droom is nou

([en die here het foto's geneem oor vanderbijilpark]; Nel, 2002:94.)

Krog sluit die bundel Kleur kom nooit alleen nie (2000) af met 'n gedig waarin sy, na al die omswerwings van liggaam en gees, haar verbondenheid aan 'n bepaalde plek openlik en eksplisiet bely:

met die litteken van tong

skryf ons die grond onder ons voete

skryf ons die ruimte waarin ons asemhaal

in jou word ruik jy mens proe jy Afrikaan

om te skryf

is om te hoort

met

my stem is vir die eerste keer vry

ons groet

almal is uitgelate

ek weet waarheen ek op pad is

tot hiertoe en verder huis

(Kleur kom nooit alleen nie; Krog, 2000:103.)

In Bosman se bundel, Landelik, is daar duidelik 'n soeke na kulturele herkoms, in positiewe en negatiewe sin. In die gedig "Reisvaardig" word die kultiverende werk van "voorsate" as 't ware nagespeur deur middel van 'n tog by die plekke langs met veral Afrikaanse name, met as verblydende konklusie: "die plekke op die kaart bestaan" (Odendaal, 2006:122). Die reis is nodig, maar in hierdie geval om die eie bestaan van die spreker as deel van 'n groep en in 'n bepaalde ruimte te bevestig. Die gebruik van Afrikaanse name gee die bepaaldheid aan die plek en vorm deel van die ruimtelike identiteitsbelewenis van die spreker in die gedig.

Dan tuis: 'n doel en nuttelose reis miskien, maar dié versekering het ons weer gekry: die plekke op die kaart bestaan.

(Landelik; Bosman, 2002:62.)

In Laurie se bundels Skietspoel (1997) en Ek sien 'n rooi bul storm (1999) speel die geografiese sowel as die natuur-, geskiedeniskode en die konflik-en-versoeningskode 'n sterk rol. In Skietspoel kom die intense verbondenheid met die natuur na vore in etlike gedigte soos byvoorbeeld in die gedig "Kameeldoring" (Laurie, 1997:14). Die kameeldoringboom beleef krag en triomf in die tyd van sy hoogbloei, maar sy groei word vernietig as hy deur die weerlig raakgeslaan word. Tog herleef die dooie boom in die klein diertjies wat die dooie stam betrek en 'n hele nuwe ekosisteem wat gevestig word. In vele 
ander gedigte praat die digter deur die natuurdinge, stel sy die bome, voëls en diere aan die woord waaruit 'n duidelike vereenselwiging met die dinge en diere van die Afrikalandskap blyk. Die gemoeidheid met die uniekheid van Afrika, sluit egter ook die mense in. In die gedig "Bibliografie" word die noue verband tussen wit en swart in Suid-Afrika uitgebeeld. Laurie gebruik 'n kunswerk waarin die vervlegtheid en interafhanklikheid van kulture in die geskiedenis van hierdie land, uitgebeeld word om die interafhanklikheid van wit en swart aan die orde te stel:

- git op wit -

'n houtsnee van Cecil Skotnes.

Met elke versreël gly

Wolraad Woltemade oor 'n baar.

Sonder die wit sou jy

die swart land nie kon besit.

(Skietspoel; Laurie, 1997:13.)

Die gedigte van die vroulike digters waarna hier verwys is, weerspieël dus 'n gerigtheid op en verbondenheid aan die kontinent waarop die digters lewe. Daar is blyke van volgehoue pogings om betekenis te gee aan hierdie verbondenheid en om tot groter begrip van Afrika en hulle plek op die kontinent te kom. Van der Merwe (1999:400) het oor vroeëre digters soortgelyke gevolgtrekkings gemaak, wat toon dat dit nie slegs vroulike digters is wat so sterk op Afrika gerig is nie. Tog bly hierdie eienskap prominent in die meeste resente poësiebundels van vroulike digters soos blyk uit die volgende voorbeelde.

Du Plooy se bundel, In die landskap ingelyf (2003), sluit af met 'n afdeling "Landskapsiklus" waarin beskryf word hoe die spreker die landskap (wat uiteindelik ononderskeibaar van die land self word) probeer verstaan en ken. Die sentrale metafoor wat gebruik word, is die van skilderwerk. Soos wat die skilder die landskap moet verstaan om dit te kan skilder, so moet 'n mens ook jou fisiese en abstrakte omgewing verstaan en ken om sinvol daarin te kan lewe. Dit word in die huidige opset 'n bykans onbegonne saak. Nogtans sluit die siklus en die bundel af met erkenning van verbondenheid, 'n belydenis van behoort, 'n besef en aanvaarding van die onvermydelike posisionering van 'n mens vir die duur van haar lewe: 
Deur oë, ore, tong en vel is ek uiteindelik 'n blote koppelvlak.

Ek is verhouding en verband tussen my tyd en hierdie land.

(In die landskap ingelyf; Du Plooy, 2003:76.)

Bosman se bundel, Landelik (2002), waarin die natuur en die platteland, 'n verbonderheid met die aarde, spesifiek met Afrika en SuidAfrika, belangrike temas is, is verder gemoeid met ' $n$ "ekologiese verantwoordelikheidsin, wat genuanseer word deur 'n duidelike religieuse besef" (Odendaal, 2006:117). Wit én swart voorgeslagte se skades en skandes, asook hulle lyding en prestasies kry erkenning. Daarom is daar ontsteltenis en skuldgevoelens oor "my verworde land", maar dit word verwoord in terme van plekke, huise, die platteland en die land.

In die verboude huise op die platteland

bloei ek oor die rakke toegemaakte boeke

en my ongebore kinders

en die stamelmooie woorde,

ontwortel, verwelkend in die stowwe

van my verworde land.

(Landelik; Bosman, 2002:36.)

Odendaal (2006:117) lees 'n hoopvolle toekomsperspektief in Bosman se verse. In die begin van die bundel, in die gedig "Landsreise I", sien sy die landskap "onbeskryflik" voor haar uitstrek. Daar word uiting gegee aan 'n soort magteloosheid, 'n gevoel dat die landskap haar oorweldig en haar tot swye bring.

Agter die wit papier

strek die landskap

onbeskryflik voort.

(Landelik; Bosman, 2002:20.)

Maar aan die einde van die bundel, in die slotgedig ("Landsreise II"), kyk sy tog anders daarna. Uit hierdie progressie blyk weereens die gelyktydige aanwesigheid van 'n bekommernis oor die komplekse problematiek van die land en die onontkenbare en onontkombare liefde daarvoor.

Hoe lief het ek dit:

die sinne wat streke skryf,

hoe lief het ek dit.

(Landreise II; Bosman, 2002:85.) 


\subsection{Ander vorms van ruimtelike metaforiek}

In Stockenström se Spesmase (1999) probeer die digter peil wat eintlik vas staan in die lewe. Met haar kenmerkende ironiese bewustheid van relatiwiteit, kom sy telkens tot 'n onthutsende slotsom. Uit die bundel spreek 'n vasbeslotenheid om sake van alle kante te bekyk en sy het 'n "spesmaas" dat niks vas en onveranderlik is nie. Tog is dit opvallend dat sy met elemente uit die fisiese omgewing werk en veral met sake wat spesifiek met Suid-Afrika en Kaapstad geassosieer word. Die digter wend haar tot Tafelberg en selfs hierdie skynbaar onversetlike en onverstoorbare berg met sy "isheid van sandsteen en graniet", word relatief ("Vanuit 'n venster bekyk", Stockenström, 1999:21). Soos wat sy die verlede en hede van SuidAfrika beleef, staan ook die ideologiese (self-) behepthede en boosaardige bedenksels wat tot geweld en verskrywing van die werklikheid en die geskiedenis gelei het, glad nie vas nie en die inherente dualisme word deur die digter uitgewys (Odendaal, 2006:116).

Hierdie isheid van sandsteen en graniet,

die voorkant steil geplet en vestinghoog,

hierdie hoogheid, hierdie deurlugtigheid

het 'n stert wat in die see steek,

en eenkant hou die duiwel

wag en anderkant 'n leeu.

En agter skulp die berg 'n baai

van volmaakte valsheid en bevaring

hy ravyne met inademing

groen, uitademing stil. Kortom,

hy staan so vas, ek dink

nie hy is betroubaar nie.

(Vanuit 'n venster bekyk; Stockenström, 1999:21.)

Op 'n boeiende wyse gebruik Stockenström dikwels metaforiek wat met konkrete ruimtelike verskynsels verband hou, maar wat uitgroei om in ' $n$ wyer sin by ander simboliese en metaforiese raamwerke aan te sluit. In die tweede afdeling van Spesmase word 'n bewuste aanvaarding van die vervlietende as wesenlike eienskap van die bestaan, ook van wat die digkuns kan vermag, eksplisiet op vele maniere verwoord. Tog gebruik die digter steeds metafore wat verband hou met plekke en dinge in die natuur. Die gedig "Gekwetter" handel oor sowel die onvatbaarheid van die werklikheid as die aard van die poësie. Die metafoor van voëls wat wegvlieg en in die niet verdwyn, is hier baie gepas. Stockenström beskryf die ontglippende aard van die korrekte woord waarna die digter altyd soek. 
Ek hemel met woorde wat nie dade word die leegheid op waarin ek my bevind.

Soos 'n gekwetter wat slapentyd sal oplos, soos 'n refrein wat herhaaldelik kwinkelerend verdwyn, toor ek my weg in taal.

(Spesmase; Stockenström, 1999:32.)

Sy probeer 'n "leegheid" beskryf, dus iets sê van die toestand waarin sy haar bevind, maar dit gebeur in woorde wat sal vergaan en verdwyn soos die geluide van voëls in die aand. Sy laat haarself ook uiteindelik in die leegheid wegraak. Die byna wanhopige aard van die skryfdaad, in die gebruik van woorde, word gesuggereer in die frase "hemel ... op" wat sowel idiomaties in die sin van "ophemel" of "deur woorde beter laat klink" gelees kan word as in terme van die assosiasie met die "hemel" as 'n abstrakte konsep wat 'n "beter" of "goeie plek" kan aandui. Dit is asof die manier waarop die digter met haar omgewing omgaan deur woorde te gebruik en nie dade nie, vergeefs is, maar nogtans ' $n$ poging is om haarself te red deur weggetoor te raak in 'n plek van "woorde".

In die tweede strofe skryf sy oor die metafisiese aard van gedigte wanneer sy sê sy is die digter wat "loop en nie / weet waarheen en nie wil / aankom en nie wil vind." Wat hier ter sake is, is dat Stockenström haar soeke uitdruk in terme van ruimtelikheid, van beweging in ruimte, van loop en die soek na 'n nie-bestaande bestemming. Sy ervaar die lewe as 'n leegheid en sy trek dit deur na die vervlietendheid van die gedig en sy aard. Sy dra die wesenskenmerke wat deel is van die lewe, naamlik gelatenheid en aanvaarding van beperkings, aan die gedig oor. Ironies genoeg staan die gedig wel daar en die betekenis van die gedig is wel behoue vir die leser.

Ontferm julle nou oor my want ek is die een wat soek en nie weet waarna en ek is die een wat loop en nie weet waarheen en nie wil aankom en nie wil vind.

(Spesmase; Stockenström, 1999:32.)

$\mathrm{Na}$ "Gekwetter" volg 'n alleenstaande gedig, "Oewergedagtes", waarin gesuggereer word dat die verwondering van die menslike gees, hoe lig en drywend, "soos 'n blaar op 'n kuil", dit ook al is, iets waardevols is. 
Die palmiet buig. Die kurper flits.

Verwondering, my eie ek, dra

'n gedagte soos 'n blaar op 'n kuil.

Die monding rek sy bek groot

en sonsoet water vloei die seë in, jubelend jobbelend tot aan die lug.

Tot daar tot daar gaan die gedagte.

(Spesmase; Stockenström, 1999:35.)

Dit is merkwaardig dat die gedig nie die waarde en betekenis van die visuele ervaring van die natuurdinge wat dit representeer, "uitsê" nie, maar dit suggereer deur die gebruik van woorde met positiewe assosiasies van skoonheid en hoop. Die "palmiet" wat buig dui op spanning wat verduur word en die "kurper flits" verwys na die vervlietendheid van 'n waarneming, maar veral na die verwondering aan die skoonheid daarvan. In "Oewergedagtes" is daar 'n suggestie van die eindeloosheid van die watersiklus wat lewe gee en die gevolglike gedurige vernuwingsproses. Die verbondenheid van die momentele ervaring met die weidsheid van die hele kosmos word gesuggereer deur die "sonsoet" water wat die "seë" invloei en al is dit so ver as wat die menslike gedagte, of die digter se gedagte kan gaan, is dit wel eindeloos verruimend. Die menslike gees kan hoopvol wees en die vervlietende ruimte van die lewe en wêreld tóg te bowe kom (vgl. ook Odendaal, 2006:120). Die waarneming van dinge is 'n konkrete ervaring, maar dit is momenteel en vervlietend. Wat wel na vore kom, is die betekenis van die dinge en hoewel die gedig dit relativeer, is die betekenis in die gedig tog standhoudender.

'n Ander digter wat op 'n eiesoortgie wyse gebruik maak van ruimtelike konsepte is Ilse van Staden. Haar gedigte roep die ruimtes van die elemente van grond, water, lug en vuur op om in die biologiese wêreld as teenvoeter van en ontvlugting aan die menslike bestaan te dien. Die elemente, wat ook uitruilbaar is, skep nuwe en veilige ruimtes waarin van die werklikheid ontsnap kan word. In die gedig "Vlerkhand" (Van Staden, 2003:7) word die elemente van grond en lug waarin die ongelukkige mens wil ontvlug deur middel van die poësie en skryf en taal, uitgebeeld:

handvlerkiges kan net oor die hemel skryf

die verskriklike grond vermy

en ontsettend teenstrydig

aan die lug geanker bly. 
Van Staden werk deurlopend met die oorskryding en transendering van ruimtelike grense. Die gedig ontstaan uit water ("Gedig aan 't kom"; Van Staden, 2003:9), maar in "Selakant" (Van Staden, 2003: $17)$ word die domein van water en "wyer plekke" teenoor mekaar gestel:

- wat is die sin

van eeue lank vertoef

in skub en vin

as wyer plekke wink?

(Watervlerk; Van Staden, 2003:17.)

Vir die digter is die lewende wese nie noodwendig gekluister aan 'n begrensde omgewing of beperkende liggaam nie. Die gedigte handel oor metamorfoses wat plaasvind, maar die transformasies word telkens ruimtelik voorgestel.

\section{Gevolgtrekking}

Hierdie artikel wil aan die hand van geselekteerde gedigte aantoon dat ' $n$ besondere bewustheid van die omringende werklikheid as ' $n$ fisiese en 'n abstrakte ruimte bestaan in die werk van vroulike Afrikaanse digters wat tussen 1994 en 2005 bundels gepubliseer het. Uiteraard kan die onderwerp hier slegs oppervlakkig behandel word en kan slegs enkele voorbeelde gebruik word. Nogtans is daar ' $n$ poging aangewend om deur eksemplariese voorbeelde aan te toon dat die literatuur iets weerspieël van die magsverhoudings sowel as die "kapitaaldraende" inhoude in die kontemporêre "veld" soos Bourdieu dit verduidelik. Inhoudelik vertoon die werk van die geselekteerde digters 'n sterk gerigte interaksie met die werklikhede van SuidAfrika en Afrika. Die kontemporêre ideologiese en kulturele problematiek is dus 'n belangrike tema in die kontemporêre veld en gedigte oor hierdie tematiek; 'n geldige produk of kapitaal wat "verhandelbaar" en waardevol is vir die rolspelers (die habitus). Die verbondenheid aan die land en die kontinent, wat kritiek en "liefdesverklarings" insluit, word egter dikwels in terme van voorwerpe in die ruimte soos bome en plante, of in terme van streke en plekke uitgebeeld (Krog, Du Plooy, Bosman).

Die voorliefde vir ruimtelike metafore strek egter verder. Daar is gevind dat die vroulike digters ook in "universele" sin van ruimtelike metafore gebruik maak soos veral blyk uit die voorbeelde uit die werk van Stockenström en Van Staden. 
Uit albei kategorieë van ruimtelike bewustheid en die representasie daarvan in die poësie soos wat in die artikel bespreek is, sou die afleiding gemaak kon word dat vroulike digters inderdaad fyn ingestel is op die ruimtes en plekke waarin hulle lewe. Of hierdie ingesteldheid sterker is as ander ingesteldhede kan nie met sekerheid beweer word nie. Daarvoor sal daar nog baie ander vergelykings getref moet word. Wat egter wel onteenseglik beweer kan word, is dat ruimtelikheid, in die wydste sin van die woord, inderdaad ' $n$ prominente faset van die digwerk van vroue in Afrikaans rondom die eeuwending na die $21 \mathrm{e}$ eeu is.

\section{Geraadpleegde bronne}

ASHCROFT, Bill. 2001. Postcolonial transformation. London: Routledge.

BELSEY, C. \& MOORE, J. 1997. The feminist reader. Great Britain: Creative Pring \& Design.

BEZUIDENHOUT, S.M. 2005. Sosio-literêre perspektiewe op die eietydse digkuns van vroue in die Afrikaanse en Nederlandse taalgebiede. Stellenbosch: Stellenbosch Universiteit. (Ph.D.-proefskrif.)

BLUNT, A. \& ROSE, G. 1994. Introduction: women's colonial and postcolonial geographies. (In Blunt, A. \& Rose, G., eds. Writing women and space: colonial and postcolonial geographies. New York: The Guilford Press.)

BOSMAN, M. 2002. Landelik. Pretoria: Protea Boekhuis.

BOURDIEU, P. 1992. Opstellen over smaak, habitus en het veldbegrip. Amsterdam: Van Gennep.

BOURDIEU, P. 1994. De regels van de kuns. Amsterdam: Van Gennep.

BOURDIEU, P. 1996. The rules of art: genesis and structure of the literacy field. Trans. by Susan Emanuel. Cambridge: Polity.

DE BEER, A.M. 2009. Ruimte as tema en metafoor in die poësie van Afrikaanse vroulike digters na 1994. Potchefstroom: NoordwesUniversiteit. (M.A.-verhandeling.)

DU PLOOY, H. 2003. In die landskap ingelyf. Pretoria: Protea Boekhuis.

HAMBIDGE, J. 2000. Lykdigte. Kaapstad: Tafelberg.

HAMBIDGE, J. 2002. Ruggespraak. Pretoria: Protea Boekhuis.

HUTCHEON, L. 1995. "Circling the downspout of empire". From: "Circling the downspout of empire: post-colonialism and postmodernism". Ariel, 20(4), 1989. (In Ashcroft, B., Griffiths, G. \& Tiffin, H., eds. The post-colonial studies reader. London: Routledge. p. 130-135.)

KROG, A. 2000. Kleur kom nooit alleen nie. Kaapstad: Kwêla.

LAURIE, T. 1997. Skietspoel. Kaapstad: Tafelberg.

LAURIE, T. 1999. Ek sien 'n rooi bul storm. Kaapstad: Tafelberg.

LEMAIRE, T. 1996. Filosofie van het landschap. Baarn: Ambo.

MOI, T. 1985. Sexual/textual politics. New York: Methuen.

MOORE-TILBERT, B., STANTON, G. \& MALEY, W., eds. 1997. Postcolonial critism. London: Longman.

NEL, R. 2002. [en die here het foto's geneem van vanderbijlpark]. Pretoria: Protea Boekhuis. 
ODENDAAL, B.J. 2006. Tendense in die Afrikaanse poësie in die tydperk 1998 tot 2003. (In Van Coller, H., red. Perspektief en profiel: 'n Afrikaanse literatuurgeskiedenis. Pretoria: Van Schaik. p. 105-127.)

ROUSSEAU, I. 2003. Die stil middelpunt. Kaapstad: Human \& Rousseau.

STOCKENSTRÖM, W. 1999. Spesmase. Kaapstad: Human \& Rousseau.

VAN DER MERWE, B.A.J. 1999. Afrika in die resente Afrikaanse digkuns. Potchefstroom: PU vir CHO. (Ph.D.-proefskrif.)

VAN STADEN, I. 2003. Watervlerk. Kaapstad: Tafelberg.

VILJOEN, L. 2002. 'n Nuwe ruimte vir Afrikaanse letterkunde. Stellenbosch: Universiteit van Stellenbosch. (Ongepubliseerde intreerede, Mei 2000.)

\section{Kernbegrippe:}

Afrikaanse vroulike digters

Du Plooy, Heilna

Krog, Antjie

Laurie, Trienke

Müller, Petra

Rousseau, Ina

ruimte as metafoor

ruimte as tema

Stockenström, Wilma

Van Staden, Ilse

\section{Key concepts:}

Du Plooy, Heilna

female poets in Afrikaans

Krog, Antjie

Laurie, Trienke

Müller, Petra

Rousseau, Ina

space as metaphor

space as theme

Stockenström, Wilma

Van Staden, Ilse 